\title{
Effect of Intervention Guidelines on Nurses' Performance Regarding Prevention and Management of Intravenous Extravasation Chemotherapy for Children
}

\author{
Basma Mahmoud Abd El-Hamed Dawoud: Assistant Lecturer of Pediatric Nursing, \\ Faculty of Nursing, Tanta University
}
Rahma Soliman Bahgat: Professor of Pediatric Nursing, Faculty of Nursing, Tanta University

\begin{abstract}
Alaa Mohammed Marie: Assistant Professor of Clinical Oncology \&Nuclear Medicine, Faculty of Medicine, Tanta University,
\end{abstract}

Sabah Mohammed El Sayed : Lecturer of Pediatric Nursing, Faculty of Nursing, Tanta University

Background: Extravasation of chemotherapy is accidental leakage of chemotherapy drugs into the subcutaneous tissue tissues surrounding the administration site. Aim of the study was to evaluate the effect of intervention guidelines for prevention and management of intravenous extravasation chemotherapy on nurses' performance. Quasi- experimental research design was used. It was carried out at Pediatric Hematology and Oncology Unit of Tanta University Hospital. A convenient sample of 20 nurses working in Pediatric Hematology and Oncology Unit and responsible for providing direct care for 50 children receiving chemotherapy. Materials and Method: Four tools were used to collect data: An assessment tool of nurses' knowledge about chemotherapy, chemotherapy administration observational checklist, extravasation scale and developed intervention guidelines. The results revealed that the total scores of knowledge for more than half of nurses were poor before the guidelines application while immediately and after one month from the guidelines application the total scores of nurses' knowledge improved and all of nurses and the majority of them obtained good scores respectively. The total score of practice for three quarter of nurses' performances were poor before the guidelines application while immediately and after one month from the guidelines application the nurses' performances improved and three quarter of nurses and more than half of them obtained good scores respectively. Conclusion: it can be concluded that there was a significant improvement in nursing staff knowledge and performance in relation to prevention and management of chemotherapy extravasation. Recommendation: In-service training program should be conducted periodically for teaching to the nurses the basic clinical skills.

Key words: Intervention Guidelines, Nurses' Performance, Intravenous Extravasation, Chemotherapy 


\section{Introduction:}

A cancer is unexpected and difficult disease when is diagnosed in a child or adolescent. The cancers of children make up less than $1 \%$ of all cancers diagnosed each year. According to American Cancer Society about 10,380 children in the United States under the age of 15 will be diagnosed with cancer in 2016. While advances in treatment have increased the survival rate for many childhood cancers ${ }^{(1,2)}$. Childhood cancer in Egypt is a growing concern for the society since its incidence has been increasing rapidly ,the high mortality rate from it in developing countries may be due to the inadequate access to medical care as there are very few hospitals or centers existing in these countries. Lack of education and knowledge of health concerns particularly relating to children have delayed many families from seeking medical help and treatment. In addition, lack of transportation for the children or obstacles concerning transportation from rural to urban places makes the available health care inaccessible ${ }^{(2)}$.

Cancer begins when cells in a part of the body start to grow out of control. There are many kinds of cancer, but they all start because of out-of-control growth of abnormal cells. Cancer cell growth is different from normal cell growth. Instead of dying, cancer cells continue to grow and form new, abnormal cells. They can also invade or grow into other tissues, something that normal cells can't do ${ }^{(3)}$.

The types of cancers that develop in children and adolescents differ from those that develop in adults. The predominant types of pediatric cancers are leukemia (26\%), cancers of the brain and central nervous system (CNS) (18\%), and lymphoma $(14 \%)^{(45)}$. Treatments of cancer in children are include surgery, chemotherapy, radiation therapy, immunotherapy, and bone marrow transplantation or stem cell transplantation. Treatment's plan depends on the type of cancer. The majority of childhood cancer treatments consist of combination of two or more of these treatments to destroy cancer cells completely ${ }^{(6,7)}$.

Chemotherapy is a type of cancer treatment that uses drugs to destroy cancer cells. Among the most common complications associated with intravenous chemotherapy drugs administration are extravasation and infiltration. Extravasation is defined as the accidental leakage of a vesicant drug or fluid from a vein into the surrounding tissue during intravenous administration. A vesicant is defined as a drug or solution which has the potential to cause blistering, severe tissue damage and even necrosis if extra vasated. 
Infiltration is the inadvertent administration of a non vesicant solution into surrounding tissues. While this may cause inflammation and discomfort, damage and necrosis rarely occurs ${ }^{(8,9)}$.

Children with cancer are at risk for extravasation because these patients often require multiple intravenous (IV) infusions, have malnourishment, need frequent administration of drugs via the IV route as well as other treatment related side effects (i.e. chemotherapy, radiation therapy) which may cause their veins to be thin, fragile and reduce the number of safe intravenous sites ${ }^{(10,11)}$.

The incidence of extravasation or infiltration is scant due to the absence of a centralized reporting mechanism of chemotherapy extravasation events. It has been reported to occur in $0.1 \%-7 \%$ of cases. In infants and children, the incidence of extravasation injury is estimated to be as high as $11 \%$ (12). Younger children are more at risk of extravasation than adults as they have small, deep veins, and diminished ability to verbally communicate their pain ${ }^{(13)}$.

Signs and symptoms of possible extravasation include:pain, stinging, burning ,Induration, erythema, swelling at the injection site, increased resistance to administration, andchanges in infusion rate ${ }^{(14,15)}$.Extravasation injury is very dangerous. It increases morbidity and may be more disabling in long term and causes delayed treatment of the primary disease. Unfortunately, these patients are poor in terms of their general conditions and are suffering from primary diseases, so prevention of extravasation is the best thing to do ${ }^{(16)}$.

Most extravasations can be prevented through the implementation of these guidelines. Chemotherapy should be given only by trained nurses and the patient should be observed frequently throughout the infusion. Patients should be informed to notify the nurse immediately if burning, pain or other unusual sensations are experienced at the infusion site. Prior to infusion, aspiration of blood is mandatory as well as flushing with saline which should be repeated at the end of the infusion. Small and fragile veins adjacent to tendons, nerves and arteries, or limbs affected by lymphoedema should be avoided $^{(17,18)}$.

Nurses have a key role to play in identification and management of intravenous chemotherapy extravasation and of course in preventing it. From maintaining a high standard of care in the delivery of intravenous drugs to managing the treatment strategy for extravasation, they have many important duties in this $\operatorname{area}^{(19)}$. 
Aim of the study: was to evaluate the effect of intervention guidelines for prevention and management of intravenous extravasation chemotherapy on nurses' performance.

\section{Research hypothesis:}

The present study was hypothesized that nurses showed an improvement on their performance regarding to prevention and management of intravenous extravasation chemotherapy for children after intervention guidelines application.

\section{Materials and Method}

\section{Materials}

\section{Research design}

A quasi- experimental research design was used in this study.

Setting: The study was conducted at Pediatric Hematology and Oncology Unit at Tanta University Hospital

Subjects: Convenient sample of all nurses working in above previously mention setting regardless of their age, years of experience and level of education with the total numbers twenty nurses. The studied nurses were working with 50 children having the following criteria:

Age ranged from 3-15 years, both sexes, diagnosed with leukemia(ALL and AML) and lymphoma(NHL and HL), receiving chemotherapy.

\section{Tools of data collection:}

Four tools were used for data collection that involves
Toole I: Nurses' knowledge regarding to chemotherapeutic agents administration

A structure Questionnaire Sheet: It was developed by the researcher after reviewing the related literature to assess nurses' knowledge regarding to chemotherapeutic agents administration. It comprised of two parts:

Part (1):a- it was covered biosocial characteristics of the studied nurses which include: Age, educational level, years of experience inside oncology Department, marital status, and attendance of related training courses.

b- Data related to child such as: age, sex, birth order and diagnosis.

Part(2): a- it was covered the nurses' knowledge about chemotherapy administration, it included; definition, classification, action, preparation, precautions during administration, potential complications, documentation and nurses' role.

b- It was covered the studied nurses' knowledge about chemotherapy extravasation as a complication of chemotherapeutic agents administration. It included: definition of chemotherapy extravasation, causes, clinical presentation and nurses' role in its prevention and management.

The questionnaire sheet contained 11 questions about chemotherapy. The nurses were asked to respond to these questions 
with only one correct response for each question before, immediately and after one month from the guidelines application . Three level of scoring for questions were be used: the correct and complete answer was scored (2), the correct and incomplete answer was scored (1), the incorrect answer and not known was scored (0). The total score was 22 which result from multiplying total number of questions, and then the result is divided by 100 to be converted into percentage. It was filled in the clinical area by the studied nurses in presence of researcher.

The total score of nurses' knowledge was calculated and classified as follow:

- $\downarrow 65 \%$ was considered poor

- $65-\quad \$ 75 \%$ was considered fair

- 75-100\% was considered good.

Tool II: Chemotherapy Administration Observation Checklist:

It was developed by researcher to assess nurses' practices before, during and after administration of chemotherapeutic agents.

\section{Scoring system for each item of practice} were be used:

- Adequately done was scored (2)

- Inadequately done was scored (1)

- Not done was scored (0)

The observational checklist was consisted of 20 items and the total score for all items in observational checklist was 40. It was filled out by the researcher.
The total score of nurses' practice was calculated and classified as follow:

- $\downarrow 65 \%$ was considered poor

- $65-\downarrow 75 \%$ was considered fair

- 75-100\% was considered good.

Tool III: Infiltration and Extravasation Scale:

It was adopted from British Columbia Cancer Agency. It was filled by the studied nurses to assess signs of infiltration or extravasation at intravenous site during chemotherapy administration. The scale parameters namely: skin color, integrity, temperature, edema, mobility, pain and fever. the scale parameters were assessed by using afivelikert scale ranged from normal(zero) to worse (4 point) except for pain scale ranged from zero as no pain , and 10 for worst pain.

\section{Tool IV: Developed Intervention}

\section{Guidelines:}

It was developed by the researcher after reviewing the related literature. It was covered the following information: definition, classification, action and preparation of chemotherapeutic agents; definition and risk factors of extravasation; its clinical signs and symptoms; specific measures followed by the nurse to prevent the risk of chemotherapy extravasation; contents of extravasation kit and general procedures for management of extravasation cases. 


\section{Method:}

1- Official permission for data collection was obtained from the administrators responsible for Pediatric Hematology and Oncology Unit at Tanta University Hospital after explanation of the study aim.

2- Nurses' consent to participate in this study was obtained after explaining the aim of the study.

3- Ethical considerations: Nurses were informed about the confidentiality of the information obtained from them and nature of the study. Children were reassured that the obtained information was used only for purpose of the study, confidentiality and privacy was maintained.

4- Content validity: Tools of the study were tested for content validity by experts in the field of pediatrics. Modifications were carried out accordingly.

5- A pilot study: A pilot study was carried out on a sample of 5 nurses to test the clarity and applicability of the study tools then the necessary modification was done. This pilot was excluded from the study.

6- Tools development: Four tools were developed based on recent literature.

7- Phases of the study: The study was conducted on three phases:
Assessment Phase: It was carried out by the researcher for all study subjects to collect baseline data, to assess the child who meet the inclusive and exclusive criteria of this study and to assess nurses' knowledge about chemotherapy(Tool I). The researcher was available 2 days per week in the previously mention setting to assess the actual nurses' performance before and immediately and after one month from application of intervention guidelines (Tool II). As all the studied nurses were observed during administration of chemotherapy in all period of morning shift.

The implementation Phase was included the following steps:

- Setting objectives

-Preparation of the content which was covered the reasons behind the application of the session.

-The studied nurses were divided into five groups and each group was consisted of four nurses.

-The intervention guidelines were carried out for each group separately through conduction of successive sessions according to the actual need assessment of the studied nurses.

-The intervention guidelines were conducted in 6 sessions, two / week. The time of each session was about 30 minutes including periods of discussion 
according to the nurses' progress and feedback.

-Different methods and media of teaching were used including lectures, group discussion

and demonstration.

- The data was collected over a period of one year from April 2015 to March 2016.

-Each group attended the following sessions:

\section{The First Session:-}

It was covering the following topics: definition, classification, action and preparation of chemotherapeutic agents. By the end of first session nurses were able to define chemotherapy, mention classification and action, they were also able to mention and list all topic discuss in this session.

\section{The Second Session:-}

It began with a review of the concepts previously presented and progress to the next level which was focused on precautions during administration and nurses' role in administration of chemotherapeutic agents. Discussion and demonstration were used to explain the role to nurses.

\section{The Third Session:-}

It was concentrated on potential complications and documentation chemotherapeutic agents. At the end of the session mothers question were answered
The Fourth Session: It began with reviewing the points previously instructed and demonstrating about chemotherapy and was focused on definition, risk factors and clinical signs and symptoms of extravasation.

The Fifth Session: It was focused on demonstrating specific measures followed by the nurse to prevent the risk of chemotherapy extravasation and the contents of extravasation kit. The content presented to nurses through discussion of related concepts and demonstration of how to apply prevention of extravasation was done through simulation on the child.

The Sixth Session: It was concentrated on demonstrating general procedures for management of extravasation cases and documentation of chemotherapy extravasation. The content presented to nurses through discussion of related concepts and demonstration of management of extravasation was done through simulation on the child.

\section{Evaluation Phase:}

Evaluation had been done before, immediately and after one month from the implementation of the guidelines.

\section{Statistical Analysis:}

The collected data was organized, tabulated, and statistically analyzed using spss software statistical computer package version 20. For quantitative variables range, mean and standard deviations were 
calculated. For qualitative variables, the number and percentage distribution were calculated. Chi-square test was used to examine the relation between qualitative variables. Fisher exact test (p) was used to compare observations before, immediately and after one month from the guidelines application. Significance was adopted at $p<0.05$ for interpretation of results of tests of significance.

\section{Results:}

Table (1) shows the biosocial characteristics of the studied nurses. It was observed that half of the studied nurses $(50 \%)$ their age were ranged from 30 to less than 35 years with mean \pm SD (32.5 \pm 3.4$)$. Regarding their education, the table reveals that $65 \%$ of nurses are graduated from secondary nursing school while $20 \%$ of them have completed their university nursing education and the rest of them have a technical nursing institute certification. Regarding their years of experience inside hematology and oncology unit it was observed that $35 \%$ of the studied nurses their years of experience were ranged from 5 years to less than 10 years with mean \pm SD $(12.44 \pm 3.52)$.In relation to their marital statusit was observed that most of them $(90 \%)$ were married and $10 \%$ were single. Unfortunately, the same table indicates that all nurses (100\%) didn't attend any conferences or training courses related to chemotherapy.

Table (2) illustrates Percentage distribution of the studied nurses' knowledge regarding chemotherapy before, immediately and after one month from the guidelines application. There were statistically significant differences in the studied nurses' knowledge regarding definition, action ,classification, side effects, precautions and documentation of chemotherapy in the child's sheet $(\mathrm{P}=0.001, \quad \mathrm{P}=0.001, \mathrm{P} \quad=0.001, \mathrm{P}=0.017$, $\mathrm{P}=0.001$ and $\mathrm{P}=0.001$ ) respectively before and immediately after the guidelines application. As regards the studied nurses' knowledge before and one month after the guidelines application it was found that there were statistically significant differences related to definition ,classification, precautions and documentation of chemotherapy in the child's sheet $(\mathrm{P}=0.001, \mathrm{P}=0.001, \mathrm{P}=0.011$ and $\mathrm{P}=0.001$ ) respectively.

On other hand there were no statistically significant differences related to the nurses' knowledge regarding action and side effects of chemotherapy $(\mathrm{P}=0.057$ and 0.077) respectively before and one month after the guidelines application. In relation to the studied nurses' knowledge immediately and one month after the guidelines application it was observed that 
there were statistically significant regarding definition, action ,classification, precautions and documentation of chemotherapy in the child's sheet $(\mathrm{P}=0.004, \mathrm{P}=0.008, \quad \mathrm{P}=0.035, \mathrm{P}=0.017$, and $\mathrm{P}=0.004)$ respectively. While there was no statistically significant difference in the nurses' knowledge regarding side effects of chemotherapy $(\mathrm{P}=0.311)$ immediately and one month after the guidelines application. guidelines application it was observed that there were statistically significant regarding definition, action ,classification, precautions and documentation of chemotherapy in the child's sheet ( $\mathrm{P}=0.004, \quad \mathrm{P}=0.008, \quad \mathrm{P}=0.035, \mathrm{P}=0.017$, and $\mathrm{P}=0.004)$ respectively. While there was no statistically significant difference in the nurses' knowledge regarding side effects of chemotherapy $(\mathrm{P}=0.311)$ immediately and one month after the guidelines application.

Table (3) represents Percentage distribution of nurses' knowledge regarding chemotherapy extravasation before, immediately and after one month from the guidelines application. It was found that there were statistically significant differences in the studied nurses' knowledge regarding definition, causes, prevention and management of chemotherapy extravasation $\quad(\mathrm{P}=0.001)$ before and immediately after the guidelines application while there was no statistically significant difference in the studied nurses' knowledge regarding signs and symptoms of chemotherapy extravasation $(\mathrm{P}=0.072)$ before and immediately after the guidelines application.

As regards the studied nurses' knowledge before and one month after the guidelines application it was noticed that there were statistically significant differences regarding definition, causes, prevention and management of chemotherapy extravasation $(\mathrm{P}=0.001, \mathrm{P}=0.002, \mathrm{P}=$ 0.010 and $\mathrm{P}=0.001$ ) respectively. Regarding the studied nurses' knowledge immediately and one month after the guidelines application it was observed that there were statistically significant differences regarding definition,

prevention and management of chemotherapy extravasation $(\mathrm{P}=0.008, \mathrm{P}$ $=0.035$ and $\mathrm{P}=0.017$ ) respectively. On the contrary there was no statistically significant differencein the studied nurses' knowledge regarding causes, signs and symptoms of chemotherapy extravasation $(P=0.072$ and $P=0.147)$ immediately and one month after the guidelines application respectively.

Table (4) represents Percentage distribution of the studied childrenregarding chemotherapy extravasation before, immediately and after 
one month from the guidelines application. There were statistically significant differences in the studied children's extravasation scale related to color , integrity, temperature of their skin, edema, mobility, pain and fever $(\mathrm{P}=0.002$, $\mathrm{P}=0.001, \mathrm{P}=0.001, \mathrm{P}=0.001, \mathrm{P}=0.012$, $\mathrm{P}=0.001$ and $\mathrm{P}=0.006$ )respectively before and immediately after the guidelines application.

As regards the studied children's extravasation scale before and one month after the guidelines application it was observed that there were statistically significant differences related to color, integrity, temperature of their skin, edema, mobility, pain and fever $(\mathrm{P}=0.009, \mathrm{P}=$ 0.007, $\mathrm{P}=0.001, \mathrm{P}=0.004, \mathrm{P}=0.032, \mathrm{P}=$ 0.003 and $\mathrm{P}=0.021$ )respectively. On the other hand it was found that there were statistically significant differences related to color, integrity, temperature of their skin, edema, mobility, pain and fever $(\mathrm{P}=$ $0.860, \mathrm{P}=0.860, \mathrm{P}=0.878, \mathrm{P}=0.872, \mathrm{P}$ $=0.872, \quad \mathrm{P}=0.959$ and $\mathrm{P}=0.629$ ) respectively immediately and one month after the guidelines application.

Figure (1)represents the total scores of the studied nurses' knowledge regarding chemotherapy and its extravasation before, immediately and after one month from the guidelines application. It was observed that the total scores for more than half of nurses $(55 \%)$ were poor before the guidelines application while immediately and after one month from the guidelines application the total scores of nurses' knowledge improved and all of nurses (100 $(\%$ and the majority $(90 \%)$ of them obtained good scores respectively .

Figure (2:)shows the total scores of the studied nurses' practice regarding chemotherapy administration before, immediately and after one month from the guidelines application. It was observed that three quarter of nurses' performances were poor before the guidelines application while immediately and after one month from the guidelines application the nurses' performances improved and three quarter of nurses $(75 \%)$ and more than half of them $(55 \%)$ obtained good scores respectively. 
Table (1): Percentage distribution of the studied nurses regarding biosocial characteristics

\begin{tabular}{|c|c|c|}
\hline \multirow{2}{*}{ Biosocial Characteristics of the Studied Nurses } & \multicolumn{2}{|c|}{$(\mathbf{n}=\mathbf{2 0})$} \\
\hline & No & $\%$ \\
\hline $\begin{array}{l}\text { Age in Years } \\
20->25 \\
25->30 \\
30->35 \\
35->40\end{array}$ & $\begin{array}{l}0 \\
8 \\
10 \\
2\end{array}$ & $\begin{array}{l}0.0 \\
40.0 \\
50.0 \\
10.0\end{array}$ \\
\hline Mean \pm SD & \multicolumn{2}{|c|}{$32.5 \pm 3.4$} \\
\hline $\begin{array}{l}\text { Educational Level } \\
\text { Secondary Nursing School } \\
\text { Technical Institute of Nursing } \\
\text { Baccalaureate Degree }\end{array}$ & $\begin{array}{l}13 \\
3 \\
4\end{array}$ & $\begin{array}{l}65.0 \\
15.0 \\
20.0\end{array}$ \\
\hline $\begin{array}{l}\text { Years of Experience in Hematology and Oncology Unit } \\
5->10 \\
10->15 \\
15->20 \\
20-\end{array}$ & $\begin{array}{l}7 \\
5 \\
3 \\
5\end{array}$ & $\begin{array}{l}35.0 \\
25.0 \\
15.0 \\
25.0\end{array}$ \\
\hline Mean \pm SD & \multicolumn{2}{|c|}{$12,44 \pm 3.52$} \\
\hline $\begin{array}{l}\text { Marital Status } \\
\text { Single } \\
\text { Married }\end{array}$ & $\begin{array}{l}2 \\
18\end{array}$ & $\begin{array}{l}10.0 \\
90.0\end{array}$ \\
\hline \multicolumn{3}{|l|}{$\begin{array}{l}\text { Attendance of any conferences or training courses related to } \\
\text { chemotherapy. }\end{array}$} \\
\hline No & 20 & 100.0 \\
\hline
\end{tabular}


Tanta Scientific Nursing Journal

Table (2): Percentage distribution of the studied nurses' knowledge regarding chemotherapy

\begin{tabular}{|c|c|c|c|c|c|c|c|c|c|c|c|c|c|}
\hline \multirow{3}{*}{ Nurses' Knowledge } & \multicolumn{4}{|c|}{$\begin{array}{l}\text { Before Guidelines } \\
(\mathrm{n}=20)\end{array}$} & \multirow{2}{*}{\multicolumn{2}{|c|}{$\begin{array}{l}\text { Immediately } \\
\text { after } \\
\text { Guidelines } \\
(\mathrm{n}=20) \\
\text { Complete } \\
\text { answer }\end{array}$}} & \multicolumn{4}{|c|}{$\begin{array}{l}\text { One Month after } \\
\text { Guidelines }(\mathrm{n}=20)\end{array}$} & \multirow{3}{*}{$\begin{array}{l}X^{2} \\
P \text {-value }\end{array}$} & \multirow{3}{*}{$\begin{array}{l}X^{2} \\
P \text {-value }\end{array}$} & \multirow{3}{*}{$\begin{array}{c}\mathrm{X}^{2} \\
\mathbf{P}-\text { value }\end{array}$} \\
\hline & \multicolumn{2}{|c|}{$\begin{array}{l}\text { Incomplet } \\
\text { e answer }\end{array}$} & \multicolumn{2}{|c|}{$\begin{array}{l}\text { Complete } \\
\text { answer }\end{array}$} & & & \multicolumn{2}{|c|}{$\begin{array}{l}\text { Incomplete } \\
\text { answer }\end{array}$} & \multicolumn{2}{|c|}{$\begin{array}{l}\text { Complete } \\
\text { answer }\end{array}$} & & & \\
\hline & No & $\%$ & No & $\%$ & No & $\%$ & No & $\%$ & No & $\%$ & & & \\
\hline $\begin{array}{l}\text { Definition of } \\
\text { Chemotherapy }\end{array}$ & 18 & 90.0 & 2 & 10.0 & 20 & 100.0 & 7 & 35.0 & 13 & 65.0 & $\begin{array}{l}{ }^{*} 32.727 \\
(0.001)^{\#}\end{array}$ & $\begin{array}{l}{ }^{* *} 14.867 \\
(0.001)^{\#}\end{array}$ & $\begin{array}{l}{ }^{* * * *} 8.485 \\
(0.004)^{\#}\end{array}$ \\
\hline $\begin{array}{l}\text { Action of } \\
\text { Chemotherapy }\end{array}$ & 12 & 60.0 & 8 & 40.0 & 20 & 100.0 & 6 & 30.0 & 14 & 70.0 & $\begin{array}{l}{ }^{\#} 17.143 \\
(0.001){ }^{\#}\end{array}$ & $\begin{array}{l}{ }^{* *} 3.636 \\
(0.057)\end{array}$ & $\begin{array}{l}{ }^{* * * *} 7.059 \\
\left(0.008^{* \#}\right.\end{array}$ \\
\hline $\begin{array}{l}\text { Classification of } \\
\text { Chemotherapy }\end{array}$ & 15 & 75.0 & 5 & 25.0 & 20 & 100.0 & 4 & 20.0 & 16 & 80.0 & $\begin{array}{l}{ }^{*} 24.000 \\
(0.001)\end{array}$ & ${ }^{* *} 12.130(0.001)$ & $\begin{array}{l}{ }^{* * * *} 4.444 \\
(0.035)^{\#}\end{array}$ \\
\hline $\begin{array}{l}\text { Side Effects of } \\
\text { Chemotherapy }\end{array}$ & 5 & 25.0 & 15 & 75.0 & 20 & 100.0 & 1 & 5.0 & 19 & 95.0 & $\begin{array}{l}{ }^{*} 5.714 \\
(0.017)^{\#}\end{array}$ & $\begin{array}{l}\text { ***3.137 } \\
(0.077)\end{array}$ & $\begin{array}{l}{ }^{* * * *} 1.026 \\
(0.311)\end{array}$ \\
\hline $\begin{array}{l}\text { Precautions during } \\
\text { Chemotherapy } \\
\text { Administration }\end{array}$ & 13 & 65.0 & 7 & 35.0 & 20 & 100.0 & 5 & 25.0 & 15 & 75.0 & $\begin{array}{l}{ }^{*} 19.259 \\
(0.001)\end{array}$ & $\begin{array}{l}{ }^{* *} 6.465 \\
(0.011)^{\#}\end{array}$ & $\begin{array}{l}{ }^{* * *} 5.714 \\
(0.017)^{\#}\end{array}$ \\
\hline $\begin{array}{l}\text { Documentation of } \\
\text { Chemotherapy in the } \\
\text { child's Sheet }\end{array}$ & 19 & 95.0 & 1 & 5.0 & 20 & 100.0 & 7 & 35.0 & 13 & 65.0 & $\begin{array}{l}{ }^{*} 36.190 \\
(0.001)\end{array}$ & $\begin{array}{l}{ }^{* * *} 15.824 \\
(0.001)^{\#}\end{array}$ & $\begin{array}{l}{ }^{* * * *} 8.485 \\
(0.004)^{\#}\end{array}$ \\
\hline
\end{tabular}

\# Significance at level $\mathrm{P}<0.05$

*Before and immediately after the guidelines application

**Before and one month after the guidelines application

***immediately and one month after the guidelines application

Vol. 12 No. 1 May, 2017 
Tanta Scientific Nursing Journal

Table (3): Percentage distribution of the studied nurses' knowledge regarding chemotherapy extravasation

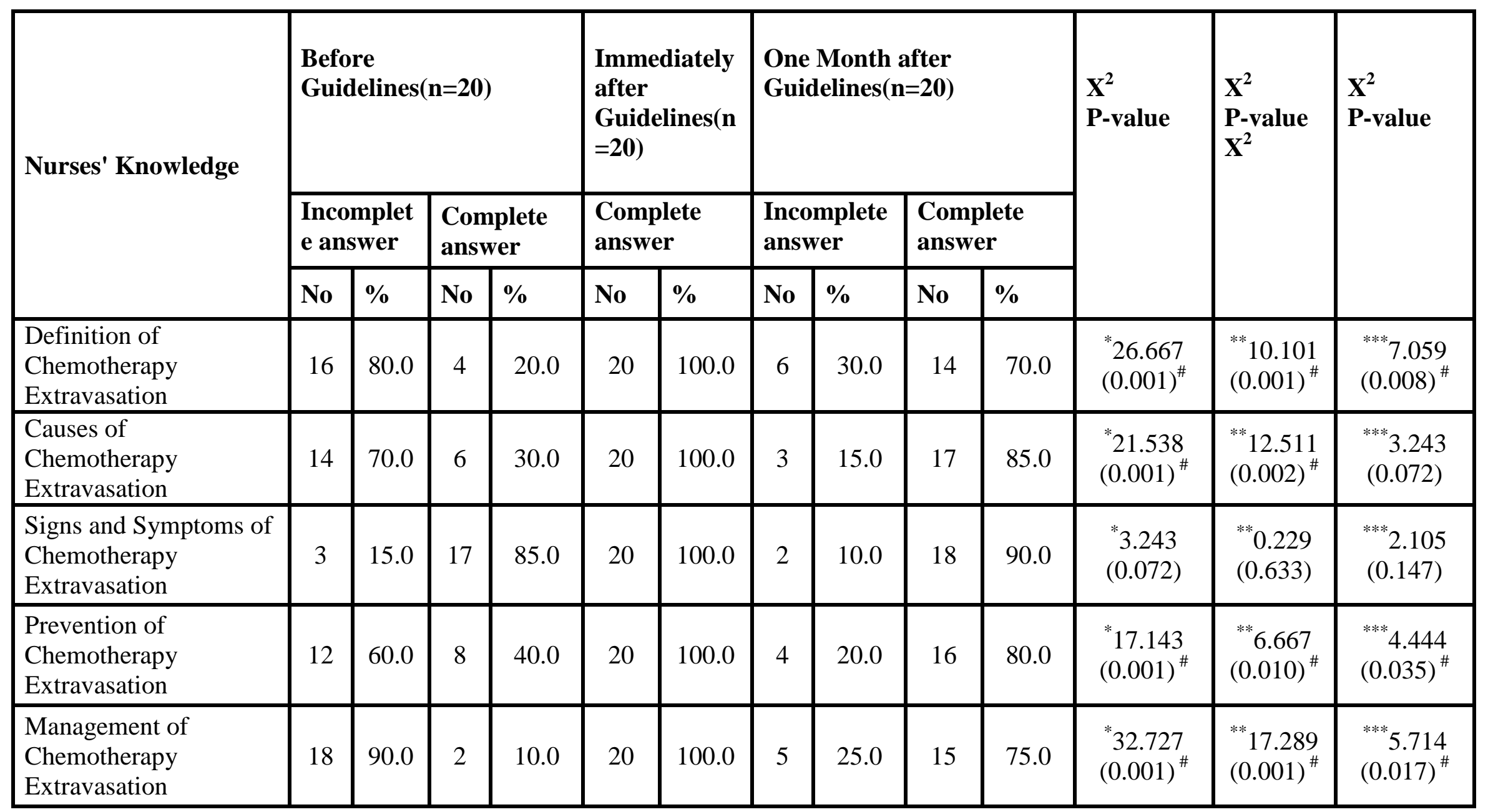

Vol. 12 No. 1 May, 2017 
Tanta Scientific Nursing Journal

Table (4):Percentage distribution of the studied children regarding extravasation of chemotherapy

\begin{tabular}{|c|c|c|c|c|c|c|c|c|c|}
\hline \multirow[t]{2}{*}{$\begin{array}{l}\text { Extravasation of } \\
\text { chemotherapy }\end{array}$} & \multicolumn{2}{|c|}{$\begin{array}{l}\text { Before } \\
\text { Guidelines } \\
(\mathbf{n = 5 0})\end{array}$} & \multicolumn{2}{|c|}{$\begin{array}{l}\text { Immediately } \\
\text { After } \\
\text { Guidelines } \\
(\mathbf{n = 5 0})\end{array}$} & \multicolumn{2}{|c|}{$\begin{array}{l}\text { One Month } \\
\text { After } \\
\text { Guidelines } \\
(\mathbf{n}=\mathbf{5 0})\end{array}$} & \multirow[t]{3}{*}{$\begin{array}{l}X^{2} \\
P \text { - value }\end{array}$} & \multirow[t]{3}{*}{$\begin{array}{l}\mathrm{X}^{2} \\
\text { P-value }\end{array}$} & \multirow[t]{3}{*}{$\begin{array}{l}\mathrm{X}^{2} \\
\mathbf{P} \text {-value }\end{array}$} \\
\hline & No & $\%$ & No & $\%$ & No & $\%$ & & & \\
\hline \multicolumn{7}{|l|}{ Skin Color } & & & \\
\hline Normal & 23 & 46.0 & 40 & 80.0 & 38 & 76.0 & \multirow{3}{*}{$\begin{array}{l}* 12.447 \\
(0.002)^{\#}\end{array}$} & \multirow{3}{*}{$\begin{array}{l}* * 9.461 \\
(0.009)^{\#}\end{array}$} & \multirow{3}{*}{$\begin{array}{l}* * * 0.301 \\
(0.860)\end{array}$} \\
\hline Pink & 7 & 14.0 & 3 & 6.0 & 3 & 6.0 & & & \\
\hline Red & 20 & 40.0 & 7 & 14.0 & 9 & 18.0 & & & \\
\hline \multicolumn{7}{|l|}{ Skin Integrity } & & & \\
\hline Unbroken & 23 & 46.0 & 40 & 80.0 & 38 & 76.0 & \multirow{3}{*}{$\begin{array}{l}* 13.263 \\
(0.001)^{\#}\end{array}$} & \multirow{3}{*}{$\begin{array}{l}* * 9.956 \\
(0.007)^{\#}\end{array}$} & \multirow{3}{*}{$\begin{array}{l}* * * 0.301 \\
(0.860)\end{array}$} \\
\hline Blistered & 23 & 46.0 & 7 & 14.0 & 9 & 18.0 & & & \\
\hline Superficial Skin Loss & 4 & 8.0 & 3 & 6.0 & 3 & 6.0 & & & \\
\hline \multicolumn{7}{|l|}{ Skin Temperature } & & & \\
\hline Normal & 20 & 40.0 & 40 & 80.0 & 38 & 76.0 & \multirow{3}{*}{$\begin{array}{l}* 16.695 \\
(0.001)^{\#}\end{array}$} & \multirow{3}{*}{$\begin{array}{l}* * 13.300 \\
(0.001)^{\#}\end{array}$} & \multirow{3}{*}{$\begin{array}{l}* * * 0.261 \\
(0.878)\end{array}$} \\
\hline Warm & 20 & 40.0 & 7 & 14.0 & 8 & 16.0 & & & \\
\hline Hot & 10 & 20.0 & 3 & 6.0 & 4 & 8.0 & & & \\
\hline \multicolumn{10}{|l|}{ Edema } \\
\hline Absent & 23 & 46.0 & 40 & 80.0 & 38 & 76.0 & \multirow{3}{*}{$\begin{array}{l}* 13.161 \\
(0.001)^{\#}\end{array}$} & \multirow{3}{*}{$\begin{array}{l}* * 10.837 \\
(0.004)^{\#}\end{array}$} & \multirow{3}{*}{$\begin{array}{l}* * * 0.274 \\
(0.872)\end{array}$} \\
\hline Non Pitting & 17 & 34.0 & 8 & 16.0 & 10 & 20.0 & & & \\
\hline Pitting & 10 & 20.0 & 2 & 4.0 & 2 & 4.0 & & & \\
\hline
\end{tabular}


Tanta Scientific Nursing Journal

\section{Cont. Table (4):}

\begin{tabular}{|c|c|c|c|c|c|c|c|c|c|}
\hline Mobility & & & & & & & & & \\
\hline Full & 25 & 50.0 & 40 & 80.0 & 38 & 76.0 & \multirow{4}{*}{$\begin{array}{l}* 10.987 \\
(0.012)\end{array}$} & \multirow{4}{*}{$\begin{array}{l}* * 8.783 \\
(0.032)^{\#}\end{array}$} & \multirow{4}{*}{$\begin{array}{l}* * * 0.274 \\
(0.872)\end{array}$} \\
\hline Slightly Limited & 17 & 34.0 & 8 & 16.0 & 10 & 20.0 & & & \\
\hline Very Limited & 5 & 10.0 & 2 & 4.0 & 2 & 4.0 & & & \\
\hline Immobile & 3 & 6.0 & 0 & 0.0 & 0 & 0.0 & & & \\
\hline \multicolumn{10}{|l|}{ Pain } \\
\hline No Pain & 20 & 40.0 & 40 & 80.0 & 38 & 76.0 & \multirow{4}{*}{$\begin{array}{l}* 17.738 \\
(0.001)^{*}\end{array}$} & \multirow{4}{*}{$\begin{array}{l}* * 14.121 \\
(0.003)^{\#}\end{array}$} & \multirow{4}{*}{$\begin{array}{l}* * * 0.305 \\
(0.959)\end{array}$} \\
\hline Mild Pain & 5 & 10.0 & 3 & 6.0 & 3 & 6.0 & & & \\
\hline Moderate Pain & 15 & 30.0 & 3 & 6.0 & 4 & 8.0 & & & \\
\hline Worst Pain & 10 & 20.0 & 4 & 8.0 & 5 & 10.0 & & & \\
\hline \multicolumn{10}{|l|}{ Fever } \\
\hline Normal & 27 & 54.0 & 40 & 80.0 & 38 & 76.0 & \multirow[b]{2}{*}{$\begin{array}{l}* 7.644 \\
(0.006)^{\#}\end{array}$} & \multirow[b]{2}{*}{$\begin{array}{l}* * 5.319 \\
(0.021)^{\#}\end{array}$} & \multirow[b]{2}{*}{$\begin{array}{l}* * * 0.233 \\
(0.629)\end{array}$} \\
\hline Elevated & 23 & 46.0 & 10 & 20.0 & 12 & 24.0 & & & \\
\hline
\end{tabular}

\#Significance at level $\mathrm{P}<0.05$

*Before and immediately after the guidelines application

**Before and one month after the guidelines application

***immediately and one month after the guidelines application 


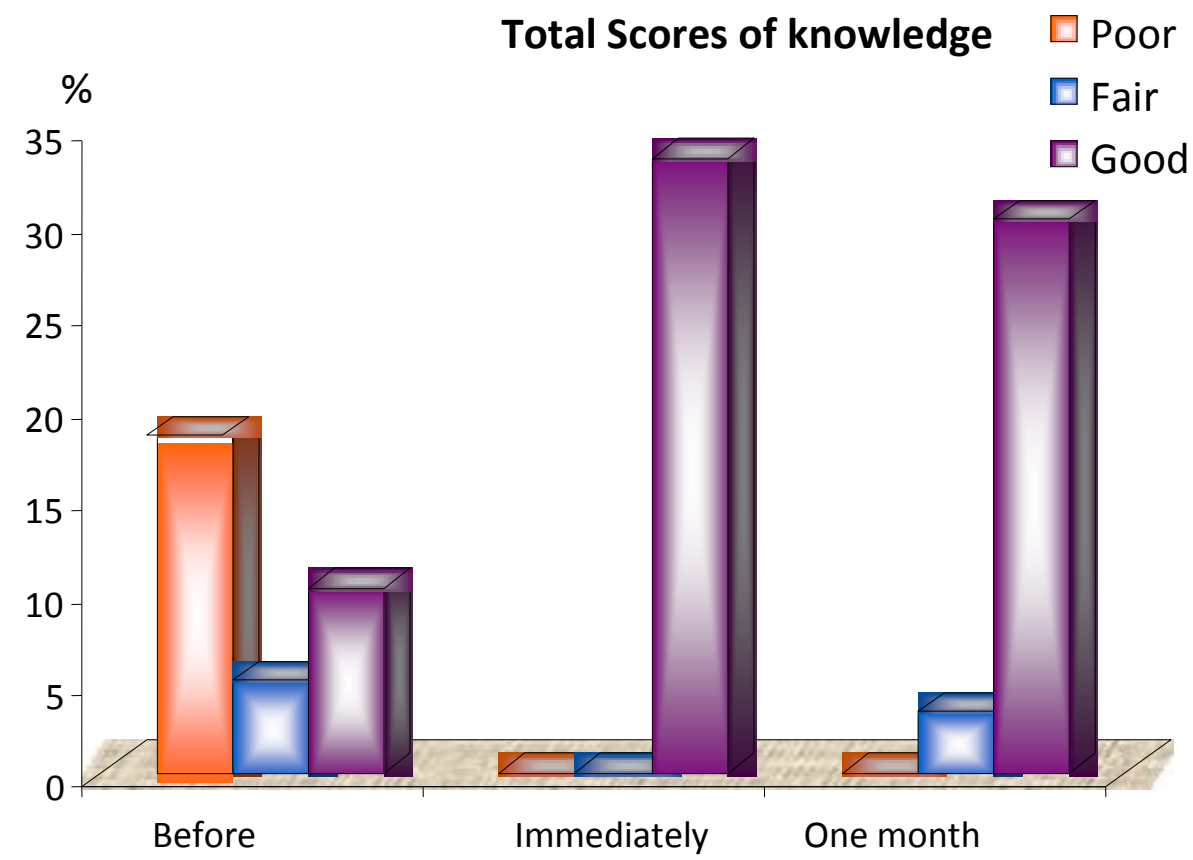

Figure (1): The total scores of the studied nurses' knowledge before, immediately and after one month from the guidelines application

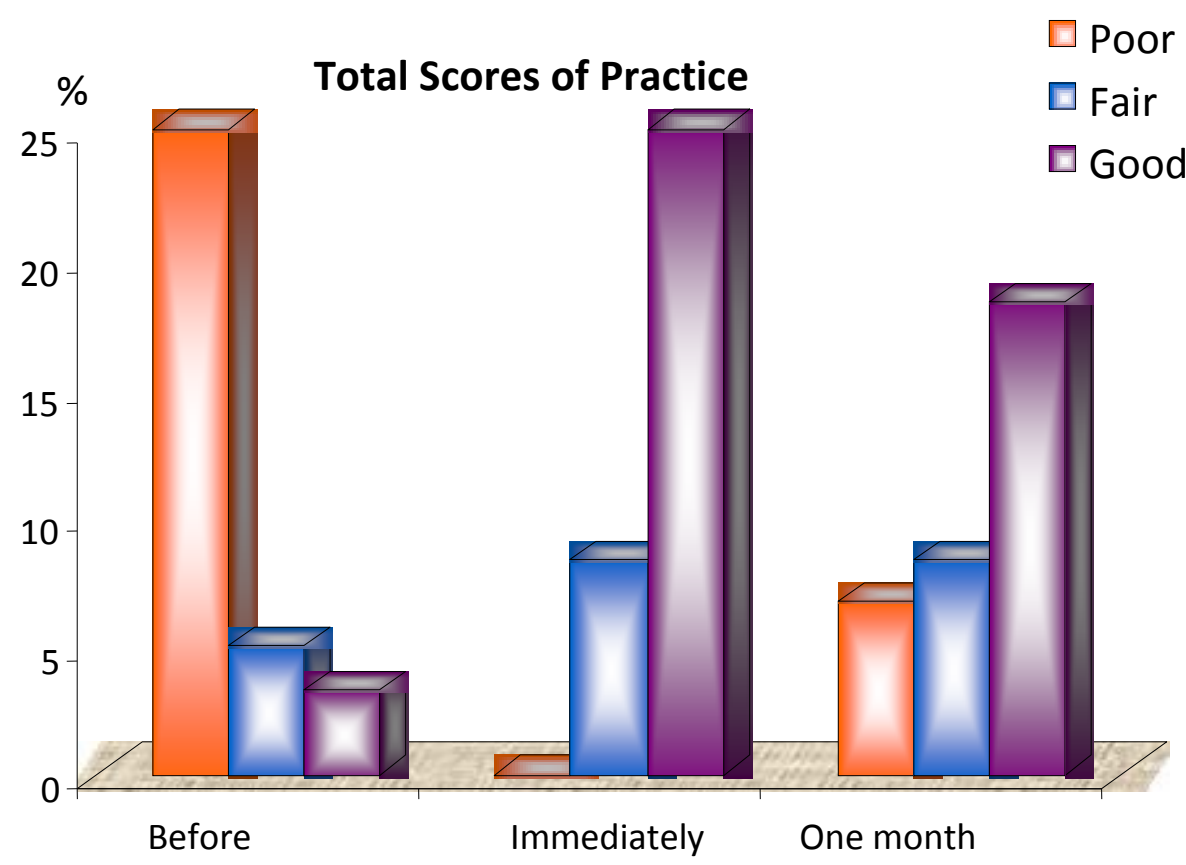

Figure (2): The total scores of the studied nurses' practice before, immediately and after one month from the guidelines application 


\section{Discussion:}

Extravasation is a potential consequence of receiving intravenous chemotherapy, and it occurs when the chemotherapy drug accidently leaks into the surrounding tissue instead of the intended intravenous administration site. Extravasation is more likely to occur when a peripheral cannula is being used, and cause severe tissue damage, tissue necrosis, and blistering into the surrounding tissues rather than into the vascular pathway as intended ${ }^{(17)}$.

Children with cancer are at risk for extravasation because they often require multiple intravenous infusions, have malnourishment, unable to complain of pain, and need frequent administration of drugs via the intravenous route. Children with cancer who receiving chemotherapy are also at a higher risk for extravasation because it may induce fragility to their veins' wall, cause their veins to be thin, and reduce the number of safe intravenous sites $(10,11)$

Nurses' qualification enable them to expand their knowledge base, grow within their field and evolve as professionals. They also raise the standard of practice throughout the profession and in the long run improve patient's safety so a highly educated nursing staff is important for delivering safe and effective patient care without them the patient's health will be at risk. Moreover, the hospital with higher proportions of nurses educated at the baccalaureate level, patients experienced lower mortality and improved outcomes $(20,21)$.

The present study revealed that slightly less than two thirds of the studied nurses had secondary nursing school. This may due to decrease hospital authorities awareness about the importance of presence of highly educated nursing staff in this critical department as nursing graduate level qualification is a significant correct predictor because if oncology nurses didn't have a dvance knowledge and not competent in their skills they will be considered as unsafe for providing chemotherapy administration to cancer patients and chances for medication errors will be high this is supported by study carried out by Corner and Barnett (2009) who found that nurses with graduation were more competent than nurses with good experience in relation to peripheral intravenous cannulation ${ }^{(22)}$.

The findings of the present study revealed that no in- service training program related to chemotherapy was given to the studied nurses. This result may be due to absence of in- service training department in the hospital, lack of motivation for training and increased workload in Pediatric Hematology and Oncology Unit. 
orientation program The findings of this study are in line with Mohsen and Fareed (2013) who found that the majority of the studied nurses didn't receive any training program related to chemotherapy (23). The main role of nurses in the oncology unit is chemotherapy administration which is sensitive domain in oncology nursing where little negligence or mistake may lead to adverse consequences for patients, staff and environment. Medication errors in chemotherapy are a common when there is a lack of specific knowledge and training of the staff about chemotherapy, prescription, preparation and administration. Therefore Nurses caring for patients receiving chemotherapy require specialized knowledge in order to ensure safety for both patients life and for their own safety ${ }^{(7)}$.

As regards nurses' level of knowledge about chemotherapy and its extravastion. The current study revealed that total scores of knowledge for more than half of nurses before guidelines implementation were poor. This may be attributed to lack of prior to work as well lack of nursing care conference during work, invariability of procedure, and books especially in this area which help nurses to get the required knowledge whenever they need. This finding was in consistent with Abd Al magid (2012) who found that more than half of nurses were having poor knowledge scores before application of nursing care standards for cancer patients undergoing chemotherapy ${ }^{(24)}$.

On the opposite immediately after implementation of guidelines the total scores of all nurses' knowledge were good. This could be attributed to the content of guidelines which was developed based on nurses' needs, its clarity and simplicity, using of audiovisual aids, availability of the teacher in the field for more clarification, using simple language, frequent repetition to fix the knowledge. This result was in line with Potter (2008) who describes that the nurse attains knowledge and competency through the standard application ${ }^{(25)}$.

The time one month after the guidelines application, this percentage was slightly reduced as the majority of nurses were having good level in all items of knowledge. This indicates that the improvement in knowledge was partially lost one month after the guidelines application. This result might be explained by the fact that, knowledge retention is usually affected by time.

Regarding nurses' level of performance related to chemotherapy administration, the results of the present study revealed that the total score of three quarter of nurses' performance was poor before guidelines 
application. This may be attributed to lack of proper equipment that needed to provide and improve nursing care and shortage of the Pediatric Hematology and Oncology Unit nursing staff. In addition to, lack of supervision and nurses' evaluation against identified standards of patient care, all these factors are behind this unsatisfactory level of practice. the of the current study was in agreement with Mohamed (2015) who found that the majority of nurses had poor practice score regarding chemotherapy administration (26).

On the contrary immediately and one month after guidelines implementation it is clearly obvious that the guidelines implementation had effectively achieved its expected objectives, nursing staff had significant higher performance score than before guidelines implementation. This can be attributed to the new knowledge and skills that the nurses acquire and they become able to apply it during their practice. The present study was in agreement with Mohsen and Fareed (2013) who noted that after implementation of chemotherapy safety protocol for oncology nurses there was an increase in the mean practice score of nursing staff ${ }^{(23)}$.

Regular training and education of all staff involved in the administration of chemotherapy and supported them by up- to-date institutional policies and procedures are important factors in providing nurses with essential knowledge and skills that enable them to minimize the risk of extravasation, detect early signs of it and manage it effectively ${ }^{(27)}$.

The present study revealed that there were statistically significant differences in the occurrence of extravasation in the studied children's before and immediately after the guidelines application. Extravasation occurrence before the guidelines application may be attributed to lack of frequent nursing observation for intravenous chemotherapy infusion and also lack of nursing instructions to patient's family about how to observe an infusion.

On the other hand there is significant reduction in the occurence of extravasation in studied children immediately and one month after the guidelines application. This may be explained in the light of increase the nurses' knowledge, awareness about prevention of chemotherapy extravasation and the eagerness of nurses to become competent in their knowledge and practice. Furthermore, nurses had the liability to change by themselves but they need an instructor and a continuous evaluation.

The findings of the present study was in harmony with El sherif (2014) who found that the educational program had a 
significant positive impact on nurses' knowledge and performance, especially in relation to objectives for minimizing chemotherapy extravasation ${ }^{(28)}$. This result was in incongruent with Schulmeister (2011) who recognised that despite healthcare providers taking every precaution and education to prevent extravasation and irrespective of the experience of the staff that administering the chemotherapy, extravasation will still occur $^{(29)}$.

\section{Conclusion:}

Based on the results of the present study, it can be concluded that there was a significant improvement on nursing staff knowledge, performance in relation to prevention and management of chemotherapy extravasation and significant reduction in extravasation occurrence in studied children.

\section{Recommendations:}

1. In-service training program should be conducted periodically and regularly for teaching to the working nurses the basic clinical skills.

2. Establishment of central in-service educational department in hospital to periodically refresh nurses' knowledge and practice regarding chemotherapy administration and stressing on the importance of documenting its extravasation
3. A special system for awarding, accreditation and certification should be taken into consideration to motivate nurses' participation and enrollment into the training and education programs which should be conducted in the work place.

\section{References:}

1. American cancer society 2016.Key statistics for childhood cancer. Available at: http://www.cancer. org/cancer/cancerinchildren/detailedgui de/cancer-in-children-key-

statistics.Retrieved at 29 September $\underline{2016}$.

2. Allen P and Vessey J. Primary Care of The Child with Chronic Condition.5th ed. Philadelphia:Mosby Co., 2008; 299-311.

3. Smith M, Seibel N, and Altekruse S. Outcomes for children and adolescents with cancer: Challenges for the twentyfirst century. Clinical Oncology Journal. $2010 ;(28): 2625-34$.

4. Assuma B. Textbook of Pediatric Nursing.7thed. Canda: Saunders:Elsevier Co.,2009;290-9.

5. Hochenberry W. Wong's Nurses Care of Infants and Children. 8thed. Philadelphia :Mosby Co.,2007;1550-9.

6. South $M$ and Isaacs $M$. Practical Pediatrics. 7thed. Philadelphia:Churchill Living stone Elsevier Co., 2012;569-72. 
7. Dipchand A and Friedman J. The Hospital For Sick Children Handbook Pediatrics.11thed. Canda: Saunders ElsevierCo.,2009;664-86.

8. Klinegman R, Stanton B, and Schor N. Nelson Textbook of Pediatrics. 19thed. Philadelphia: Elsevier Co.,2011;1112-25.

9. Terrik K. Essentials of Pediatrics 1sted. Lippincoot Williams and Wilikins Co,. 2008; 992-5.

10. Coyle C, Griffie J, and Czaplewski L. Eliminating extravasation events: A multidisciplinary approach. Infusion Nursing Journal. 2014; (37): 157-64.

11. Hadaway L. Infiltration and extravasation: preventing a complication of IV catheterization. American Journal of Nursing. 2007;107(8): 64-72.

12. Sarovath A and Kruavit A. Extravasation Injury: what is the appropriate management of extravasated skin ulcer?Thiland Journal of Surgery. 2006; 27:19-25.

13. Yarbo C, Wujcik D, and Gobel B. Cancer Symptom Management. 4thed. London: Jones and Bartlett Co., 2014; 541-44.

14. Schulmeister L. The MASCC Textbook of Cancer Supportive Care and Survivorship. Heidelberg: Springer Co., 2011; 351-60.
15. WOSCAN Cancer Nursing and Pharmacy Group. Chemotherapy Extravasation Guideline.2009; Available at: http://www.beatson. scot.nhs.uk/content/mediaassets/doc/E xtravasation\%20guidance.pdf.

Retrieved at 16 May 2012.

16. Schulmeister L. Vesicant Chemotherapy and the Management of Extravasation. Cancer Nursing Practice Journal. 2009; 8 (3): 34-37.

17. Thakur J, Chauhan C, Diwana V, and Chauhan D. Extravasational side effects of cytotoxic drugs: a preventable catastrophe. Indian Journal of Plast Surgery. 2008; $41: 145-50$

18. Jacobson J, Polovich M, and McNiff K. American society of clinical oncology: Oncology nursing society chemotherapy administration safety standards. Oncology Nursing Forum. 2009; (36):651-8.

19. Mclntosh N, Peter J, and Rosalind L. Forfar and Arneil,s:Textbook of Pediatrics. 7thed. London: Churchill Livingstone Co.,2008;991-101.

20. Aiken L, Clarke S, and Cheung R. Educational levels of hospital nurses and surgical patient mortality. American Medical Association 2012; 290(12): 11. 
21. Dawood T. Establishing Basic Standards of Nursing care for faciomaxillarypatients undergoing hip surgeries.Published Doctoral Thesis. Faculty of nursing,University of Alexandria. 2010; 92.

22. Corner $\mathbf{J}$ and Barnett $J$. The newly registered nurse and the cancer patient: An educational evaluation. International Journal of Nursing Studies.2009; (29): 177-90.

23. Mohsen $M$ and Fareed M. Safety protocol for oncology nurses. International Journal of Medical, Health, Biomedical, Bioengineering and Pharmaceutical Engineering Chemotherapy.2013; 9 (7): 529 -37.

24. Al-Magid A. Nursing care standards for cancer patients undergoing chemotherapy. Journal of American Science. 2012; 8(5):108-120.

25. Potter P and Perry A, Fundamentals of Nursing. 7th ed. Philadelphia: Mosby Co., 2008; 425 - 99.

26. Mohamed N. Effect of designed nursing protocol on nurses' knowledge and practice regarding chemotherapy, Medical Journal, Cairo University. 2015;83 ( 2): 209-216.

27. Dougherty L. Extravasation: prevention, recognition and management. Nursing Standard. 2010; (24): 48-55.
28. El-Sherif N. Nursing Management for Prevention of Peripheral Chemotherapeutic Extravasation: Evaluation Program on the Educational Outcomes of Nurses Caring of Oncology Children. Published Doctoral Thesis. Faculty of Nursing, Ain Shams University .2014.

29. Schulmeister L. Extravasation management: Clinical update. Seminars in Oncology Nursing.2011: (27); 82-90. 